\title{
Iowa's Bus Queen: Helen M. Schultz and the Red Ball Transportation Company
}

\section{MARGARET WALSH}

BUS TRANSPORTATION emerged in the United States in the 1910s and 1920s primarily as a small-scale, often family enterprise. That has made its early history difficult to trace. The few narratives that have been published so far suggest that those who entered the bus business during its early years faced fierce competition, poor trade prospects, inadequate vehicles, bad roads, and daredevil attitudes. Bus pioneers were usually men. Of the few women who did take up the challenge, the majority inherited their businesses from their husbands or their fathers and continued to run the undertakings as local ventures. Only occasionally did a female entrepreneur set up a bus company in her own right and experience the rough-and-tumble from the start. ${ }^{1}$ Among the most prominent of those pioneers was an

The research for this article was generously supported by the Nuffield Foundation and by the School of Social Sciences, University of Birmingham. The article itself would not have been possible without the assistance of Mary Martin of Mankato, Minnesota (Helen Schultz's daughter), Art Fischbeck and the staff of the Mason City Public Library, Hank Zalatel at the Library of the Iowa Department of Transportation in Ames, Mary Beveridge of Des Moines, the staff of the State Historical Society of Iowa, and the Interlibrary Loan staff of the Library of the University of Birmingham.

1. Little is known about U.S. bus pioneers. Their endeavors are buried in the memories of their children and grandchildren, in folders buried in attics or basements, or in snippets in local newspapers. Some information about men who founded companies with long life-spans or with national reputations is

THE ANNALS OF IOWA 53 (Fall 1994). CThe State Historical Society of Iowa, 1994. 
Iowa woman who came to be known nationally at the time as "Iowa's Bus Queen."

Helen Schultz and the Red Ball Transportation Company, which she established in 1922, encountered a number of challenges in the pioneering era in bus transport. First, she had to secure capital in the face of several obstacles. Then there was the battle with the state legislature and regulatory commission over the licensing of routes and other rules. Finally, operating conditions and competition from regional carriers created continuing financial stress and eventually induced her to sell her business to a regional competitor. Schultz confronted each of these obstacles in her own indomitable manner. Having established her own company, she relished the fight to keep it going. She even found ways to turn her gender, which in some ways was an entrepreneurial liability, into a public relations asset.

HELEN MARY SCHULTZ was born February 12, 1898, the second child and elder daughter of Joseph and Mary Schultz, who farmed near Nashua, Iowa, and Shell Lake, Wisconsin. She was always a strong-willed, dominant member of the family. After completing her education in local schools, she left home to attend business college in Duluth, then to earn her living as a stenographer, a respectable occupation for a young single woman in the early years of the twentieth century. ${ }^{2}$

available in Margaret Walsh, "The Early Growth of Long-Distance Bus Transport in the United States," in Theo Barker, ed., The Economic and Social Effects of the Spread of Motor Vehicles (London, 1987), 81-84; idem, "Tracing the Hound: The Minnesota Roots of the Greyhound Bus Corporation," Minnesota History 49 (1985), 311-21; Carl Gohres, "History of Pacific Greyhound Lines," ch. 1, "Auto Stage Development in California," 1-3, Greyhound Corporation Collection, American Heritage Center Archives, University of Wyoming, Laramie; Albert E. Meier and John P. Hoschek, Over the Road: A History of Intercity Bus Transportation in the United States (Upper Montclair, NJ, 1975), 1-9; Burton B. Crandall, The Growth of the Intercity Bus Industry (Syracuse, NY, 1954), 6-13.

2. Margaret Walsh and Art Fischbeck, interview with Mary Martin, Mason City, 20 May 1991; Margaret Walsh, telephone interview with Mary Martin, 15 October 1993; U.S. Bureau of the Census, Manuscript Schedules, 12th Census of the United States, 1900, Riverton Township, Floyd County, Iowa; 13th Census of the United States, 1910, Riverton Township, Floyd County, Iowa; 14th Census of the United States, 1920, Sarona Township, Washburn County, Wisconsin; Bus Transportation 2 (April 1923), 262; newspaper clippings, 
The series of temporary positions Schultz held in northern Minnesota and then in California proved fortuitous for her later career. In northern Minnesota she found a future supporter in Emmett Butler, a building contractor for whom she worked. At the offices of the Duluth, South Shore and Atlantic Railroad Company she picked up rudimentary knowledge about rail transportation. Moving on to California, reputedly to visit a girl friend from college, she 'temped' at another rail company office, the Santa Fe in Stockton, and then at the Cunard Steamship Lines in San Francisco. These jobs not only exposed her to the established world of transportation, but to the emergence of the new motor services provided by pioneer bus companies as well. The Iron Range country in northern Minnesota and the Stockton-San Francisco Bay corridor in northern California were active in the early development of bus transportation. ${ }^{3}$

By 1921 Schultz had traveled widely and gained valuable work experience. She was now eager to be her own boss. As an observant and outgoing person she had witnessed the adventure and the potential of burgeoning bus lines. Although most bus companies were operated by men, conventions were not yet firmly established in this new arena. Here was an opportunity to be seized. She could start her business in northern Iowa, where she would have family support and where there were few, if any, bus rivals. ${ }^{4}$

private collection of Mary Martin (daughter of Helen Schultz), Mankato, Minnesota. All newspaper clippings are in the Mary Martin collection unless otherwise stated. Copies of this material are available in the Mason City Public Library. Helen M. Schultz will be referred to throughout by her maiden name, the name under which she started the Red Ball Transportation Company, rather than her married name, Helen Schultz Brewer or Helen M. Brewer.

3. Helen Schultz Brewer, "Autobiographical Account," 1, Mary Martin collection; Mary Martin interview; Mary Martin telephone interview; newspaper clippings; Walsh, "Early Growth," 82-84; Meier and Hoschek, Over the Road, 1-9.

4. For a general discussion of women's proper role and women's ability to enter specific occupations in the early twentieth century, see Alice KesslerHarris, Out to Work: A History of Wage-Earning Women in the United States (New York, 1982), 217-49. Virginia Scharff examines women's early engagement with the automobile in Taking the Wheel: Women and the Coming of the Motor Age (New York, 1991). Thomas J. Morain looks more particularly at driving patterns for women in Greene County, Iowa, in Prairie Grass Roots: An Iowa Small Town in the Early Twentieth Century (Ames, 1988), 126, 131. 


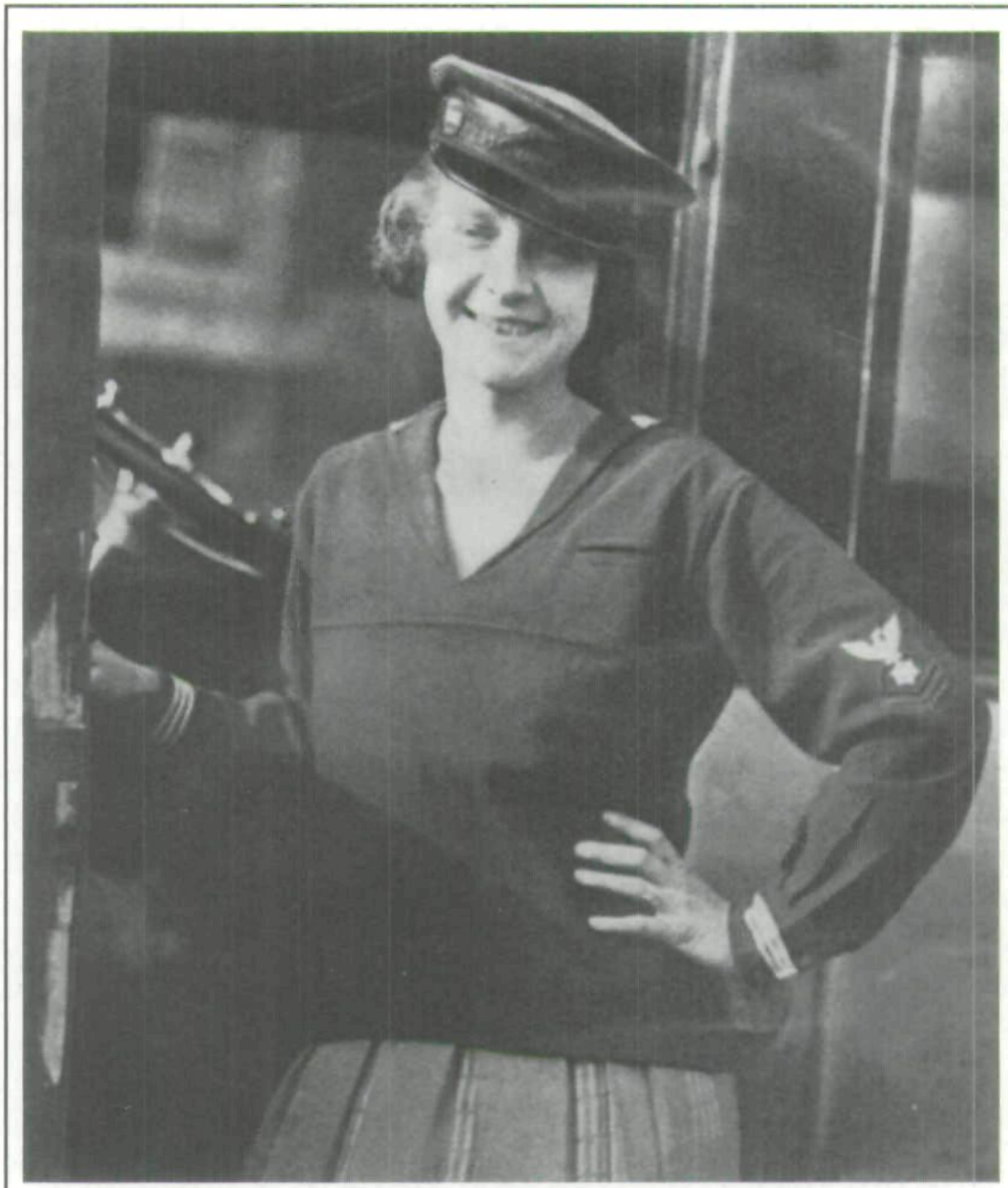

A confident Helen Schultz poses with one of her buses in 1924. The caption published with the photo read, "Although only twenty-four years of age [she was actually 26 at the time] and but a wisp of a girl, she has accomplished more in three years than most men do in an entire lifetime. Miss Schultz received her early business training as a clerk in a railroad office, and little did she think then that later she would have six powerful railroads fighting her as their keenest competitor in the state of Iowa. But . . . she knew how to fight-and won. ... Fighting railroad commissioners, city officials and powerful railroads is the hard part of her work, but she loves it." Photo from Opportunity for 1924 courtesy Mason City Public Library (hereafter MCPL). 
The opportunity was real, but Schultz faced several obstacles to realizing her dream. She would have to establish routes in a state notorious for its impassable mud roads during frequent bouts of bad weather; and the established modes of transport, namely the steam and electric railroads, were unlikely to accept buses without a fight. If the bus business did begin to look viable, rival bus companies were likely to emerge. There was much to be considered. But first, before she could establish a bus company, she needed to secure capital.

Schultz needed a capital sum of five hundred dollars for a vehicle, a reserve to cover the monthly payments on the bus, and some cash to pay her drivers, advertise in the local newspapers, and rent an office and depot. ${ }^{5}$ She hoped the line would quickly return some income from which she could cover her subsequent operating costs. Where could she get capital for a speculative business in a period when women were rarely financially independent and were not seen as a good economic risk?

Schultz's male contemporaries in the 1910s and 1920s often started up in a bus business by acquiring a second-hand auto and then operating a taxi-like service. If they got sufficient trade, they then placed a deposit on a larger, stretched-out vehicle or acquired another second-hand vehicle to run on a different short-distance route. These men either used their small savings to acquire their initial vehicle or persuaded a male friend or possibly a local bank manager to make them a loan. They then drove and maintained their autos themselves. Their modest operating costs consisted mainly of spare parts, especially tires, and gasoline. They paid for such costs out of the income generated by their bus service. If they were successful, they could expand. ${ }^{6}$

Schultz herself had some savings from her employment as a stenographer, but not enough to start a business. Stenographers generally earned from $\$ 17.50$ to $\$ 35.00$ per week, but

5. "Autobiographical Account," 1-2.

6. Walsh, "Early Growth," 82-84; idem, "Tracing the Hound," 311-16; Gohres, "Pacific Greyhound Lines," ch. 1, "Auto Stage Development in California," 1-3; Meier and Hoschek, Over the Road, 1-9; Crandall, Growth of the Intercity Bus Industry, 6-13. 
living expenses in both Minnesota and California had eaten into her earnings. Her father owned land in Iowa and Wisconsin, but his capital was locked up in his farms, so he was more likely to offer emotional than financial support. Banks generally were reluctant to loan money to single women or for untried new ventures. Schultz needed a private "backer." Fortunately, she had impressed Emmett Butler, the building contractor for whom she had worked in northern Minnesota. He was able to offer risk capital both at the onset of her bus venture and in its early years when further financing was needed for expansion. ${ }^{7}$

With the necessary capital secured, Schultz incorporated the Red Ball Transportation Company, optimistically named after the Red Ball Route, now Highway 218, a six-hundred-mile route that started in St. Paul and ended in St. Louis. She then purchased a vehicle from White Manufacturers, who had welded a bus body on a truck chassis, a normal practice in a period when specialized bus manufacturers were rare. Relying on word-of-mouth publicity, Schultz started local operation in April 1922 with two round trips daily between Charles City and Waterloo. Her bus not only picked up passengers from stated points but also when flagged down. ${ }^{8}$

Within days of making the first run, Schultz's operation was in trouble. Heavy rain broke up the dirt road, leaving her only bus stranded for two weeks halfway between Charles City and Nashua in mud up to the axles. Meanwhile, her driver, her brother Magnus, quit the risky venture in despair. Schultz remained at the depot in Charles City, parrying questions about

7. "Autobiographical Account," 1-2; unidentified statement of Helen Schultz, n.d., Mary Martin collection; newspaper clippings, c. 1923 and 1947; Opportunity for 1924, 10, Mary Martin collection; Mary Martin interview; St. Paul City Directory 54 (1918), 119; ibid. 56 (1920), 22, 303; ibid. 61 (1925), 91, 274; ibid. 68 (1932), 65, 232; Theodore Christianson, Minnesota: The Land of Sky-Tinted Waters, vol. 3, Minnesota Biography (Chicago, 1935), 69-70; Sharon H. Strom, Beyond the Typewriter: Gender, Class, and the Origins of Modern American Office Work, 1900-1930 (Urbana and Chicago, 1992), 208.

8. "Autobiographical Account," 1-3; newspaper clippings, c. March 1947; "Iowa Registered Highway Routes, 1914-1925," an insert map in William H. Thompson, Transportation in Iowa: A Historical Summary (Ames, 1989); Walsh, "Tracing the Hound," 313; idem, "Minnesota's 'Mr. Bus': Edgar F. Zelle and the Jefferson Highway Transportation Company," Minnesota History 52 (1991), 308. 


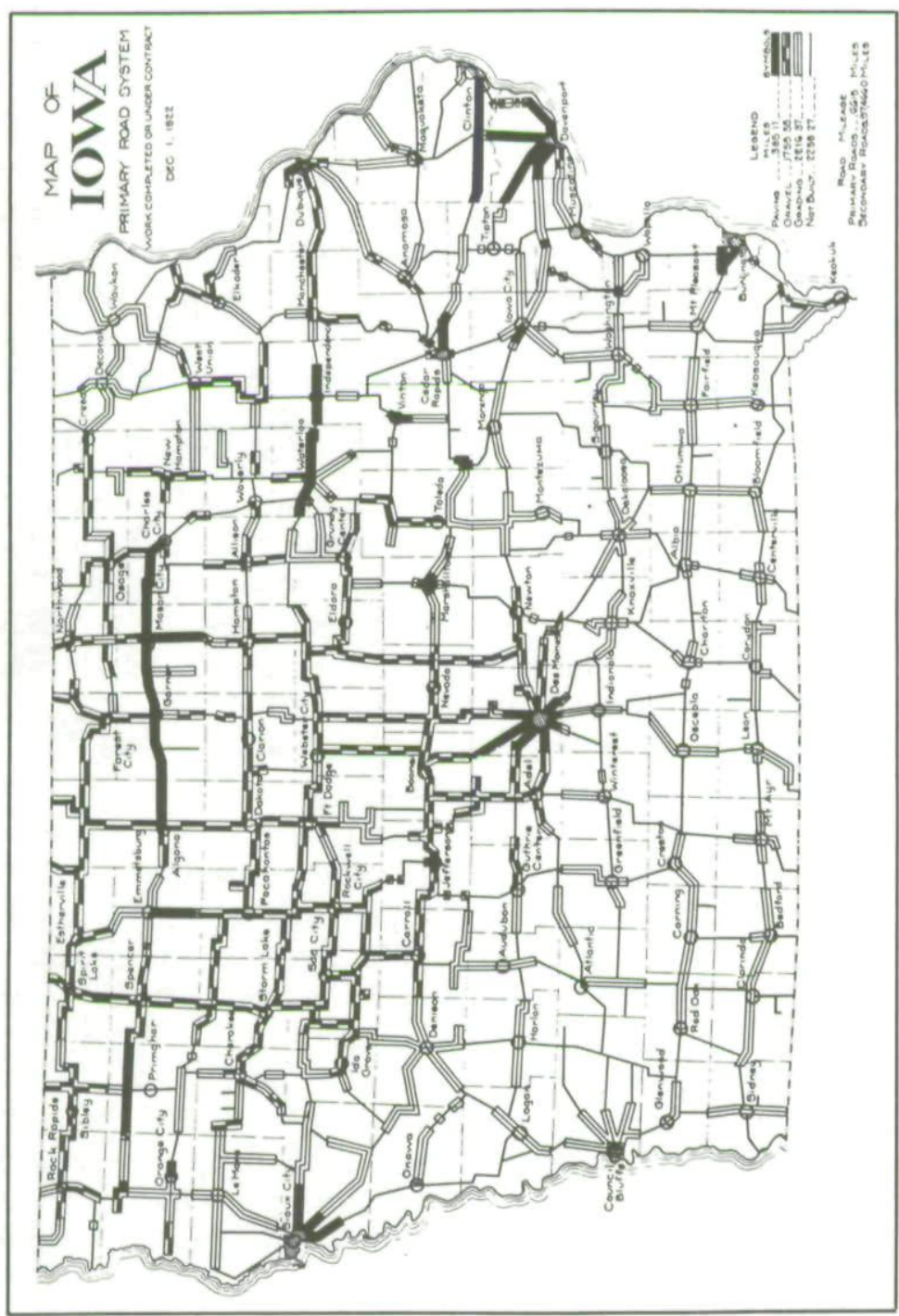

This map of Iowa's primary road system appeared in 1922 in the Iowa State Highway Commission Service Bulletin. Primary roads were those roads that were part of the state road system established in 1919. Note the relatively long stretch of paved road (solid line) from Charles City through Mason City to Algona. For the Red Ball Transportation Company's routes, see the advertisement reprinted on page 348. 
the future of her bus line. She was determined to continue. She had both her self-respect and her capital investment to salvage. ${ }^{9}$

When the weather allowed the bus to be rescued, Schultz hired a driver to help make the bus runs, and she gradually built up a clientele that included women shoppers and traveling salesmen. But traffic was not large enough to provide a sound income. She needed to open a route to Mason City, the regional manufacturing and trading center, to attract more customers. As an additional incentive, there was a concrete road from Mason City to the summer resort of Clear Lake and a paved road under construction to Charles City. Such roads would eliminate many obstacles and delays. But Schultz needed another bus. Fortunately, the sales representative from the White Company was anxious to sell more vehicles and offered a contract on a second bus. As business grew she acquired a third vehicle later that year for the evening express run from Mason City to Waterloo. By that time her brother Magnus felt confident enough about the prospects of the company to re-enter the business as her partner. ${ }^{10}$

Schultz may have emerged from the mud to establish her business, but she was by no means secure in 1922. The Speedway Motor Coach Company soon provided fierce competition. Operated by a Chicago entrepreneur who also recognized Mason City's potential as a bus entrepôt, that company quickly established a route to Charles City. It attempted to squeeze out the Red Ball Company by running its buses on a slightly earlier schedule - a tactic that led to several altercations between the bus drivers of the two companies and occasional overnight jail visits. Such competition was "like a nightmare" to Schultz, but, she later recalled, "my jaw was set and my drivers were loyal." She moved her main office from Charles City to Mason City, thereby providing a convenient bus depot as well as a headquarters from which she could orchestrate a publicity campaign. She quickly demonstrated the advantages of better motor vehicles

9. "Autobiographical Account," 1-3; newspaper clippings, c. March 1947.

10. "Autobiographical Account," 4-5; newspaper clipping; Concrete Highway Magazine 10 (April 1926), 81-83; Mason City Globe Gazette, 1 June 1953; J. H. Wheeler, comp. and ed., History of Cerro Gordo County, Iowa (Chicago, 1910), 337-41; W.P.A. Guide to 1930s Iowa (1938; reprint, Ames, 1986), 285-87. 


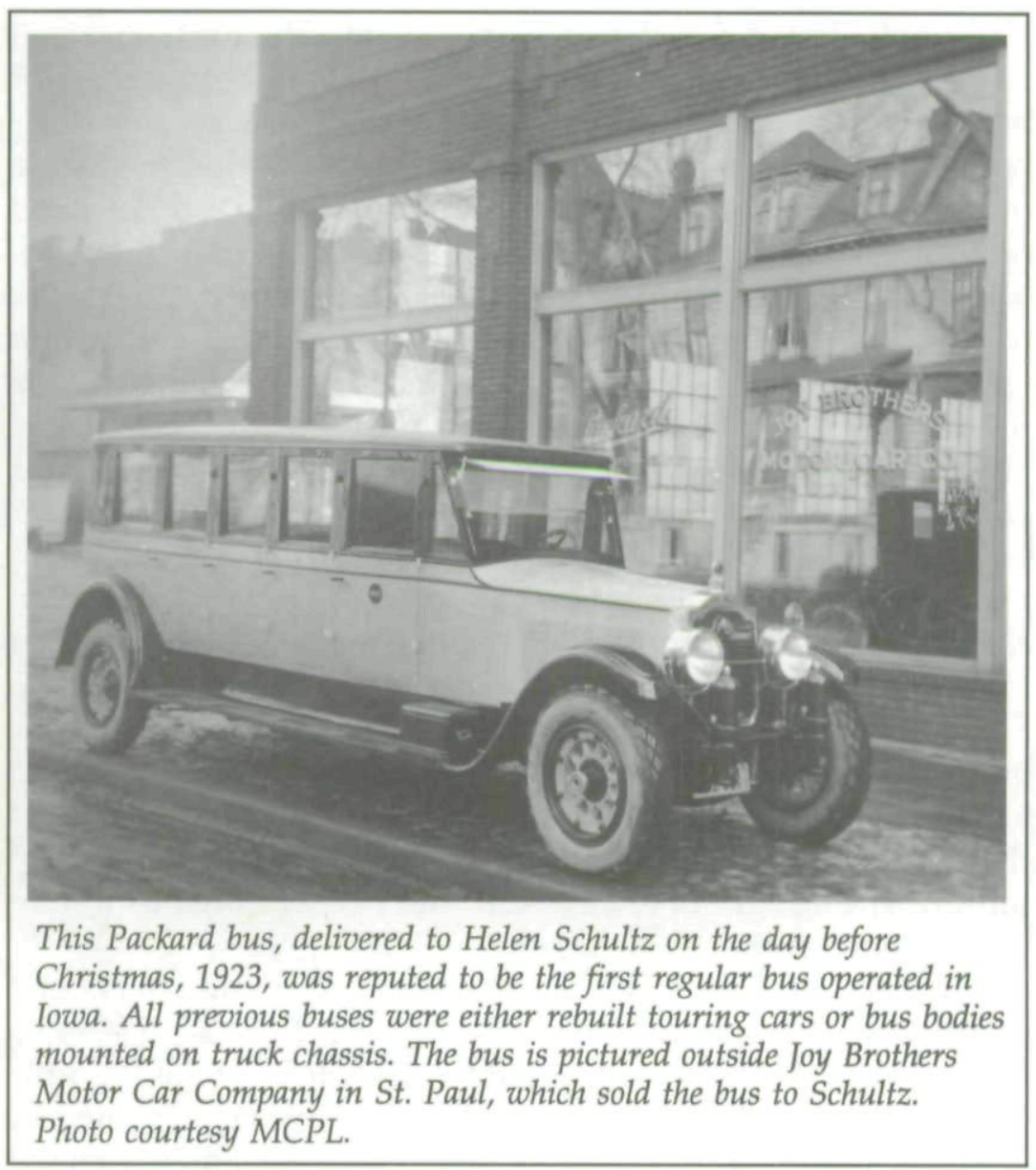

and her longer through services to Waterloo. The out-of-town bus company retired temporarily only to return later in the year with faster and better equipment. By then, however, Schultz had acquired more buses, was offering more frequent service, and had started a new route from Mason City to Des Moines. She was building a reputation for reliability, and her presence as a local entrepreneur enabled her to outmaneuver interlopers. ${ }^{11}$

11. "Autobiographical Account," 4-10; newspaper clippings, c. March 1947; Red Ball Transportation Company "Time-Table," effective 2 October 1922, Mary Martin collection. 
HELEN SCHULTZ had managed to fend off an intercity bus rival during her first year of business, but competition was not her only operating problem. She still faced considerable difficulties in establishing the legitimacy of her business in some of the towns she served. When she started her company, bus operations in Iowa were not regulated. Using local ordinances, town and city governments decided whether to impose a tax or a license fee or whether to allow buses free use of urban streets. A few cities, such as Waterloo, welcomed the new mode of transport as a means of enhancing their economic position, but most towns worried about the expenses involved and demanded some user fee. Schultz was prepared to pay a vehicle tax, but she was not prepared to pay several local taxes of varying amounts. She became caught up in legal cases contesting local ordinances that imposed fees. She was not alone in this struggle. For example, two of her rivals, the Speedway Company and the Star Transportation Company, both of Mason City, had carried out successful challenges to local license fees. By the end of 1922 it became apparent that the state needed motor carrier legislation that would apply uniformly throughout Iowa and would be monitored by a state government authority. ${ }^{12}$

In April 1923 the Iowa General Assembly vested the Board of Railroad Commissioners with the power to prescribe regulations for the operation of motor carrier lines. Like the railroads, motor carriers would be subject to rules established in the public interest. All intercity bus lines would have to have a certificate authorizing their business, and they would have to provide information on their schedules and their property. They would also have to keep records of their business and pay the required taxes. Schultz was entitled to operate under this new law because she had "grandfather rights," but in order to obtain her certificate to operate she needed to show that she was already in business before the law went into effect. She could do that in most places, but she also had to

12. "Autobiographical Account," 11-13; Bus Transportation 2 (April 1923), 262; ibid. (May 1923), 260. 
establish that her routes were "convenient." That would be more difficult. ${ }^{13}$

When Schultz had started her bus line in 1922, there was already a viable transportation network in northeastern Iowa. Steam railroads, electric interurbans, and the automobile offered residents mobility over both short and longer distances. For example, Mason City had six passenger-carrying railroads, Waterloo four, and Charles City three. To connect with these lines and for traveling from one local community to another, rural Iowans were turning from the farm buggy to the automobile, especially Ford's Model T. Better roads enabled such auto usage to become more reliable. ${ }^{14}$ The "convenience" of the Red Ball Transportation Company would be challenged on the grounds that it was stealing established passenger business.

The initial challenge came from the electric interurban, the Mason City and Clear Lake, which charged that the Red Ball Transportation Company had not been operating in good faith

13. 1923 Laws of Iowa, 90-95; Iowa Board of Railroad Commissioners, FortySixth Annual Report (1923), 96-101 (hereafter cited as IBRC, Report); Interstate Commerce Commission, "Coordination of Motor Transportation," Docket 23400, Reports 182 (1932), Appendix F, 410-13. Iowa legislation initially required only the promotion of public convenience by motor carriers, whereas other state legislatures approved necessity and convenience statutes. Contemporary legal opinion suggested that Iowa lawmakers nevertheless intended to control the competition of public utilities. They thought that the sole word convenience covered the requirements. See W. S. Ingram and M. S. Breckenridge, "Motor Bus Competition with Established Carriers," Iowa Law Bulletin 9 (1923-24), 268-90.

14. For general information on transportation in Iowa, see Thompson, Transportation in Iowa, 83-165. For information on specific modes of transport, see Keith L. Bryant, Jr., ed., Railroads in the Age of Regulation, 1900-1980 (New York, 1988); George W. Hilton and John F. Due, The Electric Railways in America (Stanford, CA, 1964); and John F. Rae, The Road and the Car in American Life (Cambridge, MA, 1971). For more specific information on the impact of transportation on rural life in Iowa, see Morain, Prairie Grass Roots, 109-40. The passenger carrier railroads running into Mason City were the Chicago and North Western, the Chicago Great Western, the Chicago, Milwaukee, St. Paul and Pacific (the Milwaukee Road), the Chicago, Rock Island and Pacific, the Milwaukee and St. Louis, and the Mason City and Clear Lake; those running into Waterloo were the Chicago Great Western, the Chicago, Rock Island and Pacific, the Illinois Central, and the Waterloo, Cedar Falls and Northern; those running into Charles City were the Illinois Central, the Milwaukee Road, and the Charles City Western. 
on a specific route between Mason City and Clear Lake prior to April 14, 1923, when the motor vehicle legislation went into effect. Helen Schultz and her brother needed to prove to the satisfaction of the Iowa Board of Railroad Commissioners that they had established that service. The issue turned on the bus company's frequent and special service to the summer resort of Clear Lake during the summer of 1923 (after the April 14 cutoff date). If the electric railway company opposed that service because adequate provision already existed, then the Red Ball line could lose the route. If, however, either the Mason CityClear Lake section of the bus company's longer route from Mason City to Algona or its brief special service of September 1922 between the two points was recognized as legitimate, then its right to the route would be allowed. ${ }^{15}$

The majority decision of two to one, with Chairman Fred Woodruff dissenting, disallowed the Red Ball Company's special summer service, although it did authorize the company's regular service between Mason City and Algona, making a stop at Clear Lake. The initial legal battle at the state level demonstrated that buses could not operate wherever their owners wanted. Schultz tried again the following year to obtain permission to use Clear Lake as a regular terminal. She fought throughout the summer to establish the route, and both she and her drivers faced arrest, jail, and fines. She later claimed that on July 4, 1924, she wrote "thirty-two $\$ 100.00$ checks to free my drivers each time they were jailed" for their attempts to take excursionists to and from Clear Lake. Her efforts were in vain; the route belonged to the railway company. She had to be content with establishing a new service between Clear Lake and Bayside, another lake resort where there was no other competing public land transport. ${ }^{16}$

The legal contest over the Mason City-Clear Lake route was a preliminary skirmish for the longer and larger battle with the more powerful steam railroads. They also contested several bus

15. IBRC, Report (1923), 110-12; Des Moines Register, 24 October 1923; newspaper clipping, c. November 1923.

16. IBRC, Report (1924), 198-200; Mason City Globe Gazette, 4 July 1924; Helen M. Schultz, "True Facts Regarding the Adjoining Write-Up," typescript in Mary Martin collection. 


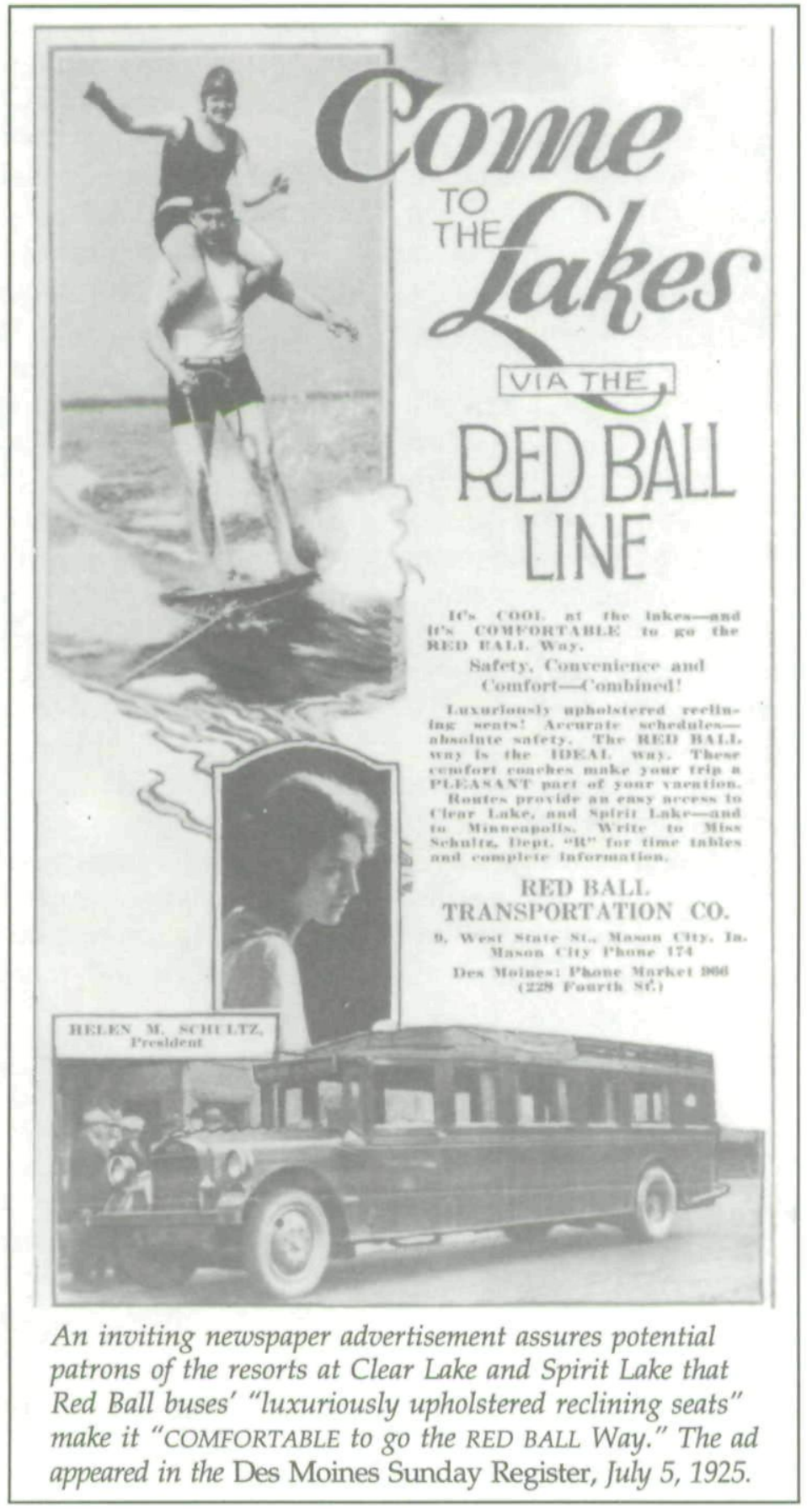


routes on the grounds that a convenient service was already available for Iowans. Schultz requested that the hearings on those routes scheduled for September be postponed until October 23 so that she could better prepare her case. Although heavily in debt, she was still committed to further expansion. By the fall of 1923 she had eleven large 24-seater coaches, some of which were up-to-date models costing eleven thousand dollars each. To acquire these, she had managed to borrow some capital from local banks. If she were forbidden from operating over some routes, then her financial viability would be threatened. Not only was her livelihood at stake; the consequences of the struggle had broader implications. The Red Ball Transportation Company was the leading bus enterprise in Iowa. Even though it was capable of providing faster and better service than some of the railroads, the future development of the new mode of transport in the region would be threatened if Schultz's company could not succeed in establishing its routes. ${ }^{17}$

Schultz was convinced that she was legally entitled to run her business, but she knew that her confidence was not enough to keep her company in operation. She needed evidence of "convenience." To obtain that evidence, she had to demonstrate grass-roots support. She, her family, her employees, and her friends proceeded to gather lists of signatures from patrons testifying that the bus service was both advantageous and essential. Such documentation was designed to impress on the Board of Railroad Commissioners the positive and popular response to buses. ${ }^{18}$

As she began buckling on the gauntlets for the biggest fight of her meteoric business career, Schultz also recognized that she needed a wider promotional effort. She began to capitalize on her newsworthy image as an attractive and plucky young woman fighting the mighty railroad corporations. "The railroads and interurban companies are determined to 'get' me if they can,"

17. "Autobiographical Account," 19-24; Fageol Motor Company, It's Always "Fare Weather" (1924), Mary Martin collection; newspaper clipping, c. November 1923; Opportunity for 1924, 10; Mary Martin interview; "First National Bank of Mason City," typescript, 2, Mason City Public Library.

18. "Autobiographical Account," 14-20; newspaper clipping, c. October 1923. 
she told one reporter. "Well I'm not going to be gotten unless I have to be. And if they put me out of business here, well I'll just simply take my little busses some place else and start a few new lines." ${ }^{\prime 19}$ Well before the hearings began, the Des Moines Register named her the "Iowa Bus Queen." The title stuck—as did her age; she was perennially 24 years old, the age at which she had started the Red Ball Transportation Company in 1922. Newspapers in other parts of the United States reported similar struggles of male bus pioneers to maintain their routes against railroad pressures, but rarely were those struggles so dramatic or romantic. Such a good story could not be neglected by either Schultz or the media.

The three members of the Board of Railroad Commissioners were aware of the growing publicity in favor of the Iowa Bus Queen. Their duty, however, was to serve the public interest. They knew that the electric and steam railroads were not alone in opposing buses. Commercial clubs, such as those in Northwood, Manly, and Kensett, thought that bus companies did not pay taxes commensurate with the capital involved in their business. Farmers and county supervisors claimed that the heavy vehicles ruined road surfaces, and many residents worried about the speed of the buses and the danger of road accidents. ${ }^{20}$ The commissioners also had to take into account motor carrier legislation in other states. By the end of 1922, nineteen states had made legal provision for intercity buses, and the issue was being discussed in five other states in addition to Iowa in $1923 .^{21}$ Even though buses were gaining legitimacy elsewhere, Schultz knew that at least one of the commissioners, Charles Webster, was firmly opposed to bus lines. She would need to make a strong case.

At the October hearings in Des Moines, two of the five routes of the Red Ball Transportation Company were contested: the one between Mason City and Des Moines and the one from

19. Newspaper clipping, c. 1923; Opportunity for 1924, 10-11, 44-45; Mary Martin interview.

20. IBRC, Report (1923), 115-19; Des Moines Register, 24, 25 October 1923; newspaper clipping, c. 1923.

21. Interstate Commerce Commission, "Coordination," Appendix F, 410-13. 
Mason City to the Iowa-Minnesota state line. Those routes were opposed by five steam railroads - the Chicago and North Western, the Minneapolis and St. Louis, the Chicago Great Western, the Chicago, Rock Island and Pacific, and the Chicago, Milwaukee and St. Paul-by one electric interurban (the Fort Dodge, Des Moines and Southern), by the supervisors of various counties through which the routes passed, and by some local commercial interests, including farmers. Initially, the Jefferson Highway Transportation Company, another ambitious bus firm that wanted to extend its routes through northern Iowa to Des Moines, had been in contention with the Red Ball Company. After consultation, however, the two bus firms decided to resolve their differences and stand together against the railroads in order to protect the infant bus industry in Iowa. ${ }^{22}$

In making their decision the railroad commissioners considered the issues of damage to the highways, harm to the railroads' business, danger to the public, and the efficiency of the company's operations. For example, they deliberated whether the establishment of bus routes would so cripple rail services that they would not be able to operate, but decided that it was not in their brief to speculate on future developments. The commissioners also decided not to surmise whether the railroads would suffer "a gross injustice" because they were taxed more heavily than motor vehicles. In the end, their decision turned on their interpretation of their charge to promote "the public convenience." After hearing many Iowans testify that buses were useful, the commissioners agreed to grant permits to the Red Ball Company because it provided a convenient service. The Iowa Bus Queen had won her fight to establish a new mode of transport that was competitive with existing modes. ${ }^{23}$

Her victory, however, had its downside. Both Commissioner Lewis and Chairman Woodruff thought that motor carriers should pay adequately for highway use and that, like the railroads, they should be subject to regulation. Commissioner

22. IBRC, Report (1923), 104, 105, 112, 113; Des Moines Register, 23, 24 October 1923.

23. IBRC, Report (1923), 114-19; Des Moines Register, 24 October, 22 November 1923; Bus Transportation 2 (December 1923), 599. 
Webster worried about the excessive speed of buses and their destructive impact on gravel roads. The commissioners thus insisted that bus schedules should not compete directly with those of existing companies, that buses should not exceed the speed limit of 25 miles per hour, and that all passengers should pay the stated fares. Failure to comply with these provisions would result in a loss of license. ${ }^{24}$ Schultz declared that she was satisfied with the judgment. Her buses already operated within the speed limit, she claimed, and she did not like giving out free passes as incentives because they undermined the economic viability of her company. She had what she wanted - the right to stay in business. In a statement to the trade magazine, Bus Transportation, she said, "I am naturally very happy over the outcome of my petitions. ... My bus business is the pride of my life and I love my buses." 25

THE IOWA BUS QUEEN now looked forward to building up her bus line. Difficulties abounded, however. Like other bus pioneers, she found that it was a constant struggle to provide regular, comfortable, and economical service. The weather and poor road conditions often interfered with schedules. Investment capital remained scarce, while increased operating costs cut into profit margins. Furthermore, the 1923 legislation made it difficult to open up new routes. Schultz also faced managerial problems that could not always be resolved by the direct and often confrontational style she had adopted. It might well be acceptable to drive one of her own buses, but engaging in verbal and physical showdowns with officials and rivals and being arrested for failing to comply with the law did not necessarily gain more passengers. Schultz had used her gender and her youth to advantage, but they had less impact as the bus industry matured and became more conventional.

In the face of such operational problems in the mid-1920s, Schultz, never content to delegate responsibility to lieutenants,

24. IBRC, Report (1923), 114-19; 1923 Laws of Iowa, 95; Des Moines Register, 22 November 1923.

25. Des Moines Register, 22 November 1923; Bus Transportation 2 (December 1923), 599. 


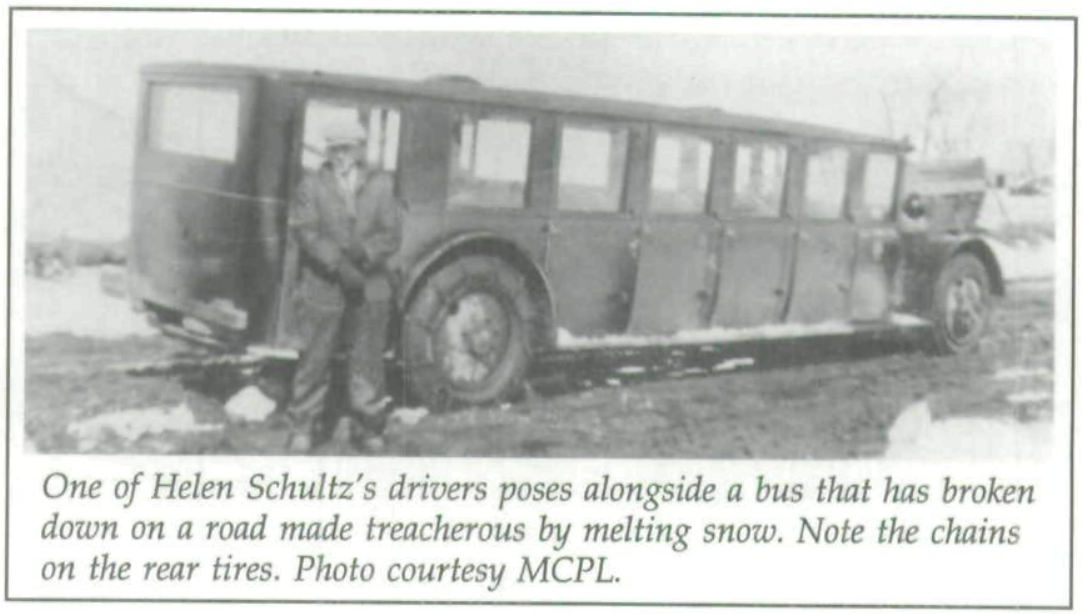

took personal charge. When heavy snow blocked the roads out of Mason City in February 1924, she did not wait for county officials to act or for nature to take its course. She recruited a gang of eighteen men and personally superintended the clearing of the snow on three highways. Hoping to make the most of the good publicity both for herself and for her business, she then announced to the press that she would experiment with motor snow plows herself. The weather would not defeat her. ${ }^{26}$

Vehicle breakdowns, often caused by punctured tires, were a more common problem. Drivers always traveled with a spare tire and a repair kit, and passengers knew that delays were possible on any trip. Schultz, herself capable of repairing and changing tires, became annoyed when punctures caused interruptions to her schedules. On one occasion, after a lengthy breakdown, she is reputed to have been so incensed that she threw a hammer through the windshield when the bus did arrive. Fortunately, the driver ducked. ${ }^{27} \mathrm{He}$ knew that the Bus

26. Bus Transportation 3 (February 1924), 93.

27. Margaret Walsh, interview with Robert Tracy, St. Paul, Minnesota, 2 October 1985; Walsh, "Minnesota's 'Mr. Bus,'" 313; Mary Martin, telephone interview. Some of the best information about the problems of driving early buses can be found in oral interviews with pioneer drivers. See, for example, Arthur B. Lennartson, 16 December 1974; Paul D. Silliman, 18 June 1975; Allen Tamadge, 24 October 1975; Merle Hemphill, 7 June 1976 - all in Iron Range Research Center, Chisholm, Minnesota. 
Queen could be irascible if all did not go smoothly. She wanted to show the world that she was capable of running a reliable business in an arena dominated by men.

That business was becoming one of consolidation rather than expansion in the middle and late 1920s. Having won her fight with the railroads, Schultz had hoped to enlarge the Red Ball Company either by opening new routes or by purchasing existing routes from rivals. Already in possession of routes stretching from Des Moines north to the state line, and from Mason City west to Spirit Lake and Algona, east to Charles City and then south to Waterloo, she found that she could make only minor alterations to her established business in northern Iowa, and there were few opportunities to move farther afield. Her application for a route between Waterloo and Cedar Rapids, for example, was denied, not only because the railroads claimed that adequate service already existed, but because motor bus service was also available. Now that state motor carrier legislation was in force, the competition between bus lines, as well as with railroads, was regulated in the public interest. It was more important to provide adequate and reliable service than to increase the number of new routes. ${ }^{28}$

Perhaps it was just as well that Schultz's expansion plans were restricted, because venture capital was scarce. By the mid1920 s the cost of new "state-of-the-art" vehicles ranged between eight and fourteen thousand dollars each. ${ }^{29}$ Deposits for the purchase of these vehicles required loans. Schultz had already used up her personal savings and had borrowed from family and friends. Local banks had offered some assistance, but they resisted more, partly because they themselves were in difficulties and partly because of prejudice against bus operators and

28. IBRC, Report (1927), 101, 103, 114, 116, 123, 124, 125, 132; ibid. (1928), 136; ibid. (1929), 90-91, 106-7, 110, 135; Des Moines Register, 9 November 1924; Red Ball Transportation Company, "Bus Schedule," n.d. [c. mid-1920s], Mary Martin collection; Concrete Highway Magazine 10 (April 1926), 81-83; Bus Transportation 5 (August 1926), 458.

29. Des Moines Sunday Register, 9 November 1924; newspaper clipping, c. 1927; Bus Transportation 5 (October 1926), 591; Edgar F. Zelle and Northland Transportation Company, "Agreement," Exhibit No. 1, 11 July 1925, Edgar F. Zelle Records, Jefferson Lines, Minneapolis. 


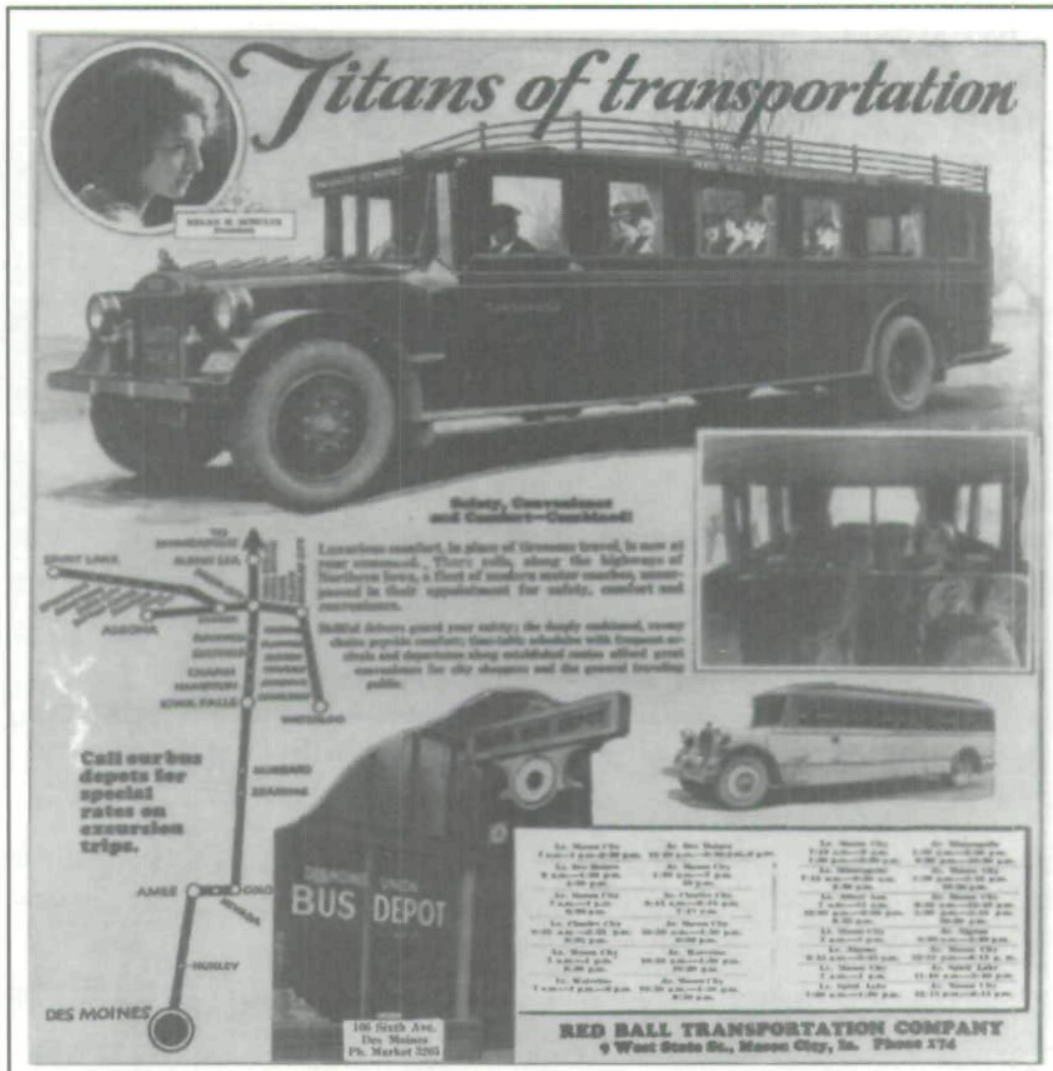

This newspaper advertisement lists schedules and assures potential customers of the "safety, convenience, and comfort" of routes extending from Des Moines north to the state line, and from Mason City west to Spirit Lake and Algona, east to Charles City, and then south to Waterloo. The ad appeared in the Des Moines Sunday Register, November 9, 1924.

against women entrepreneurs. Ideally, the Red Ball Company should have been generating sufficient profit to reinvest in the business, but by 1927 it was running at a loss. That year there was a deficit of $\$ 7,419$, and losses continued in subsequent years. Incoming revenue was insufficient to cover expenses, let alone to finance the purchase of modern equipment. ${ }^{30}$

30. "Autobiographical Account," 20-24; IBRC, Report (1927), 422; ibid. (1928), 397; ibid. (1929), 427; ibid. (1930), 315; ibid. (1931), 338. 


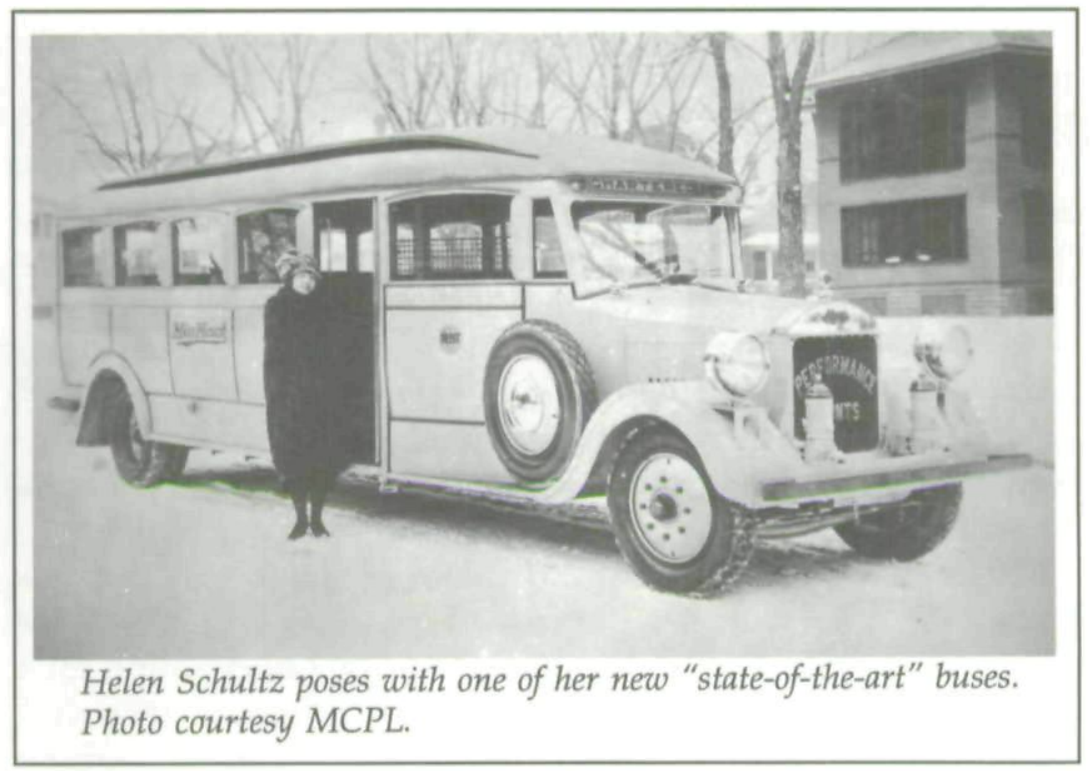

The Iowa Bus Queen's financial troubles were not uncommon. Several other large bus companies in Iowa ran deficits in the late $1920 \mathrm{~s} \mathrm{~s}^{31} \mathrm{~A}$ combination of factors-economic conditions in rural Iowa, burdensome taxes, and increasing competition among bus companies - contributed to their plight.

Iowa's economic condition in the middle to late 1920s was not as prosperous as it had been earlier in the century-a period often called the "golden age of agriculture." ${ }^{12}$ During that period of prosperity, farmers had increased their output,

31. In 1927 six of the ten Class I carriers - those with an annual gross revenue of thirty thousand dollars or more-operated at a loss. In 1928 and 1929 the respective figures were five out of fifteen and six out of twelve. IBRC, Report (1927), 421-22; ibid. (1928), 395-97; ibid. (1929), 426-27; ibid. (1930), 314. The 1926 figures were classified differently. The "Class A Motor Passenger Carriers" had an annual operating revenue above fifty thousand dollars, and two of the five companies, including the Red Ball Company, were in deficit.

32. For a general overview of farm conditions in the region, see Theodore Saloutos and John D. Hicks, Agricultural Discontent in the Middle West, 19001939 (Madison, WI, 1951). For Iowa, see Leland L. Sage, "Rural Iowa in the 1920s and 1930s: Roots of the Farm Depression," Annals of Iowa 47 (1983), 91-103; Joseph F. Wall, "The Iowa Farmer in Crisis, 1920-1936," ibid., 116-27; and Morain, Prairie Grass Roots, 212-46. 
productivity, and investments, but in the 1920s they faced diminishing demand and falling prices. Their distress, in turn, depressed the rural economy.

In such a situation bus traffic might have declined or stagnated. But that did not seem to be the case for all large carriers. Official statistics show a 90 percent increase in passengers for companies with annual revenues of thirty thousand dollars or more, rising from about 1.5 million passengers in 1927 to more than 2.5 million in 1929, while the Red Ball Transportation Company saw its number of passengers decline by 4 percent in those years. ${ }^{33}$ A weak rural economy may have impeded local bus expansion, but it could not account for all poor performances.

State taxes added to the difficulties of Iowa bus entrepreneurs. All motor vehicles needed a license, and after 1925 all owners or operators paid a gasoline tax. A wheelage or ton-mile tax was levied on motor carriers beginning in 1923. That controversial tax was based on a bus's full capacity regardless of how many passengers were carried. When the Iowa legislature doubled the tax rate in 1925, the Iowa Motor Vehicle Association, of which Schultz was secretary, challenged the constitutionality of the law on the grounds that it was discriminatory. An injunction restrained the state commission from collecting the tax until the law was validated, and the association set aside money to pay the tax if and when it became necessary. ${ }^{34}$

33. How much of the overall increase came from out-of-state passengers is unclear. Operators with only or primarily Iowa passengers showed mixed records. The Fort Dodge, Des Moines and Southern Transportation Company had a passenger increase of 76 percent, while the Motor Coach Division of the Waterloo, Cedar Falls and Northern Railway Company and the Red Ball Transportation Company had passenger decreases of 1 and 4 percent in those years. IBRC, Report (1928), 396-97; ibid. (1929), 447; ibid. (1930), 324; ibid. (1931), 347; ibid. (1932), 355. Before 1930, the statistics in the IBRC Report do not differentiate between revenue passengers within and with-out the state of Iowa. Companies that listed high percentages of passengers as out-of-state, namely Interstate Transit Lines, Northland Transportation Company, Burlington Transportation Company, and Jefferson Transportation Company, were responsible for an increasing percentage of passengers after 1928 .

34. The tax amounted to one-eighth of one cent per ton mile of travel on vehicles with pneumatic tires and double that amount for those with solid tires. For buses, the full seating capacity was multiplied by 150 pounds per passenger and added to the weight of the bus, the driver, and any supplies. 
All motor carriers claimed that the wheelage tax was unfair because it did not apply to irregular operators such as transfer, dray, and taxi-cab companies whose daily business was to different points. Many thought legislators had been influenced by the railroad lobby, which sought to cripple the emerging bus industry. Certainly in the mid-1920s the Iowa tax on buses was one of the highest in the United States, and it caused considerable difficulties for any company operating below average seating capacity. For Schultz the tax was a nightmare, costing her some $\$ 1,700$ a month. When the Iowa supreme court upheld the constitutionality of the ton-mile tax law late in 1928, the Red Ball Transportation Company was reputed to owe the state nearly fifty thousand dollars in taxes. ${ }^{35}$ Schultz might have been able to face that tax bill with more equanimity had she not been confronted with the more serious challenge of regional bus competition.

By the late 1920s the structure of the infant bus industry was changing. Intercity operations were consolidating at the regional level, and long-distance interstate lines were emerging to offer through bus transportation across the continent. Iowa's location on east-west routes from Chicago to the West Coast and on northsouth routes from the Canadian border through the Twin Cities to Kansas City made it attractive to ambitious interstate companies, which sought to take over local companies with legal rights to key routes. The Red Ball Transportation Company held rights to routes in central and eastern Iowa that could form part of a major north-south link. ${ }^{36}$

1923 Laws of Iowa, 90-95; 1925 Laws of Iowa, 4; Bus Transportation 4 (January 1925), 44; ibid. (February 1925), 97; ibid. (May 1925), 217; ibid. 5 (February 1926), 111; ibid. 6 (February 1927), 117; ibid. 7 (January 1928), 52; The Truck and Bus Owner 2 (November 1923), 6; Mason City Globe-Gazette, 7 January 1929; newspaper clippings; George S. May, "The Good Roads Movement in Iowa," Palimpsest 46 (1965), 102-4.

35. IBRC, Report (1927), 422; ibid. (1928), 397; ibid. (1929), 442; ibid. (1930), 326; Bus Transportation 6 (February 1927), 115; ibid. 7 (January 1928), 52; ibid. (November 1928), 644; Mason City Globe Gazette, 7 January 1929; newspaper clippings; Memo, "Bus Mileage and Passengers," President's Subject File 11532, Great Northern Railway Company Records, Minnesota Historical Society, St. Paul.

36. Bus Transportation 7 (May 1928), 251-54; ibid. (October 1928), 523-26. 
Schultz had experienced mixed success in attempting to consolidate her position in Iowa. In 1926 she joined with steam and electric railroads and motor bus operators to defeat the application of Hawkeye Stages of Des Moines for some routes across central Iowa. The following year, however, she failed to prevent the Waterloo, Cedar Falls and Northern Railway Company from establishing a bus route between Waterloo and Mason City. In 1929 she failed again to obtain permission to open a line between Waterloo and Cedar Rapids because there was already rail passenger service and bus service over part of the route. Despite such failures she was still well placed to withstand the competition of local Iowa firms. ${ }^{37}$ She could not, however, take on stronger bus competition in the form of the Minnesota-based Jefferson Highway Transportation Company.

Headed by Edgar F. Zelle, that company wanted to establish routes in Iowa in order to reach St. Louis or Kansas City. The company had operated to Mason City for several years, using both interline connections with the Red Ball Company at Albert Lea and its own through route. But Zelle needed more connections and other routes. In 1927 he opened direct runs from Austin, Minnesota, to Charles City and from Rochester, Minnesota, to Decorah. The following year he extended the Decorah service to Cedar Rapids and Independence, the Charles City service to Waterloo, and, most significantly, he reached Des Moines via Garner and Ames. In 1929 he successfully gained access to Kansas City by the central Iowa route through Des Moines and Osceola to the state line and then through Missouri. ${ }^{38}$

The Jefferson Company's expansion program did not go unopposed. In 1923 Schultz had agreed with the previous owners

37. "Autobiographical Account," 14-15, 18-19; IBRC, Report (1926), 116-18; ibid. (1927), 114-16; ibid. (1929), 90-91, 106-7; Des Moines Evening Tribune, 4 March 1926; Mason City Globe Gazette, 14 December 1928, 23, 27 February 1929; newspaper clippings, c. 1927.

38. IBRC, Report (1927), 117, 133, 139; ibid. (1928), 70, 75, 78-81, 101-3, 114, 117, 123, 137, 141, 142; ibid. (1929), 88, 90-91, 93, 99, 100-4, 106-7, 108, 140, 141, 142; Minnesota Railroad and Warehouse Commission, Auto Transportation Company Division, Biennial Report (1926), 66, 68-72, 162; ibid. (1928), 121-22, 175-77, 291-92; ibid. (1930), 197-98; Jefferson Transportation Company, Timetables, 1926-1929, Minnesota Historical Society; Walsh, "Minnesota's 'Mr. Bus,'" 311-12, 313-14. 
of the company to share the Albert Lea, Minnesota, to Mason City route only so that the bus companies could present a united front against the railroads. In 1928, when Edgar Zelle sought to establish first interstate and then intrastate lines to Cedar Rapids, he met resistance not only from the railroads, but also from Schultz. In moving southward through Iowa to Kansas City he was again opposed by the railroads, who were joined by the emerging bus giant, Pickwick-Greyhound Lines of Chicago. The search for mid-continental bus routes that could be linked into a regional or a national network required the acquisition of established Iowa companies. ${ }^{39}$

Edgar Zelle had decided to build a strong regional bus company, but his progress in realizing his ambition increasingly depended on merging his lines with Schultz's. He knew that he was unlikely to obtain a permit to duplicate her key routes, so he proposed either coordinating schedules or preferably buying her out. ${ }^{40}$ Initially, Schultz preferred coordination, but by early 1930 she was contemplating selling. Competition was no longer small-scale, and many local operators were under financial pressure to sell out at a profit. Pickwick-Greyhound Lines, a part of the Motor Transit Company, which would shortly become the Greyhound Corporation, was interested in the northsouth through route. Two other giants, the Yelloway System, through its subsidiary, Pioneer Stages of Oakland, California, and Interstate Transit Lines of Omaha, part of the Union Pacific Railway Company, were interested in the east-west routes. Although the mergers that would create the transcontinental bus systems were not clear in 1929 and 1930, local Iowa bus owners could see the advantages of selling their routes to well-financed out-of-state corporations. ${ }^{41}$ When Edgar Zelle, owner of the

39. IBRC, Report (1923), 104, 105, 112, 113; ibid. (1927), 78-81; ibid. (1928), 101-3; ibid. (1929), 90-91, 99-104, 106-7; Des Moines Register, 23, 24 October 1923; Mason City Globe-Gazette, 23 February 1929.

40. Edgar F. Zelle to Helen M. Brewer, 7, 30 August 1929; Brewer to Zelle, 3, 24 August 1929, Edgar F. Zelle Records; Jefferson Transportation Company, Timetables, 1924-1929; Mason City Globe-Gazette, 13 June 1930.

41. IBRC, Reports (1929-1931); "The Greyhound Corporation," typescript, Greyhound Corporation Collection; "Corporate History of Interstate Transit Lines," typescript, Union Pacific Railroad Company Collection, Nebraska State Historical Society, Lincoln; Bus Transportation 8 (March 1929), 168-69; ibid. (June 1929), 350-52; Mason City Globe-Gazette, 16, 31 October 1929. 
smallest of those companies, offered to buy out Schultz in June 1930 for two hundred thousand dollars, she decided to retire from the bus business. ${ }^{42}$

It was a wise decision. She probably could not have survived the emerging competition. She was already in financial difficulties because her company was not profitable. The accumulated wheelage tax of some fifty thousand dollars was a drain on her financial resources. Furthermore, she needed to invest capital in both motor coaches and buildings. Of the eleven buses in service in 1929, only four were reputed to be in sound condition. Ticket offices, waiting rooms, and garages needed to be modernized, and more staff were required to manage particular facets of the operation, such as advertising, legal affairs, accounting, and bus scheduling. She did not have the capital, nor was she likely to be able to borrow it, to carry out such improvements. Moreover, her style was not bureaucratic. She was accustomed to taking direct action when competitors stood in her way: she had tongue-lashed railroad attorneys and government officials who opposed her bus lines, and she had defied the law, risking fines and imprisonment for contempt of court. Such a feisty fighter would not take kindly to a more administrative role. ${ }^{43}$

NEITHER HELEN SCHULTZ nor the routes of the Red Ball Transportation Company faded away when she quit the bus business. The Jefferson Highway Transportation Company developed its newly acquired Iowa routes as part of a strong midwestern operation. The Minneapolis-based company weathered the difficult years of the Great Depression, enjoyed increased trade during World War Two, and then successfully adjusted to the competition from other modes of transport in the postwar years. It still remains a sound company. ${ }^{44}$

42. "Articles of Agreement for the Sale of the Red Ball Transportation Company to the Jefferson Transportation Company," 16 June 1930, Edgar F. Zelle Records; Mason City Globe-Gazette, 13, 17 June 1930; Des Moines Tribune, 13 June 1930.

43. IBRC, Reports (1927-1931); newspaper clippings; Mary Martin interview; Margaret Walsh, Mary Martin, and Art Fischbeck, interview with Robert Tracy, former Red Ball and Jefferson Company driver, 20 May 1991, Mason City.

44. Walsh, "Minnesota's 'Mr. Bus,'" 314-22. 
Schultz used part of the profits from the sale of the Red Ball Company to move laterally in motor transport. She invested in a one-stop automobile service station and Firestone tire agency, the Brewer Tire and Battery Company. Once again she was featured in local headlines in several court cases involving the running of the business and the payment of taxes. She continued to fight corporations and the law in the same confrontational manner she had adopted while running her bus line. She and her husband, Donald Brewer, whom she had married secretly in Omaha in 1925, did not remain long in the new business before moving to the Twin Cities. They later moved back to Iowa to live either in Mason City or on the family farm near Nashua, where Donald Brewer reluctantly became a farmer. On the death of her father in 1946, Helen Schultz inherited his fourhundred-acre property. She gained title after a legal suit involving her brother Magnus, and then sold the farm at a profit in 1950. She continued to assert her strong will in whatever venture she undertook until her death in 1974, even though she did not always win her fights and though the strain of fighting took its toll. ${ }^{45}$

Helen Schultz is one of the small number of bus pioneers, let alone female bus pioneers, who have a recoverable past. She gained her reputation as a forceful woman in a man's world. She may have hoped to establish a sound business with longterm prospects, or she may have been searching for adventure or personal fulfillment. Her ability to remain in operation for eight years in a period when women were not welcome in business circles and when men systematically excluded women from entry to the professions was a remarkable achievement.

45. Mary Martin, interview; Mary Martin phone interview; miscellaneous newspaper clippings, 1927, 1930s and 1940s, Mary Martin collection and Mason City Public Library collection; Bus Transportation 6 (February 1927), 124. Helen Schultz was able to continue as active head of the Red Ball Company after her marriage because her sister Margaret kept house and looked after her son Donald and her daughter Mary. Helen Schultz died in Cascade, Iowa, March 8, 1974. Dubuque Telegraph-Herald, March 10, 1974. 
Copyright of Annals of Iowa is the property of State of Iowa, by \& through the State Historical Society of Iowa and its content may not be copied or emailed to multiple sites or posted to a listserv without the copyright holder's express written permission. However, users may print, download, or email articles for individual use. 